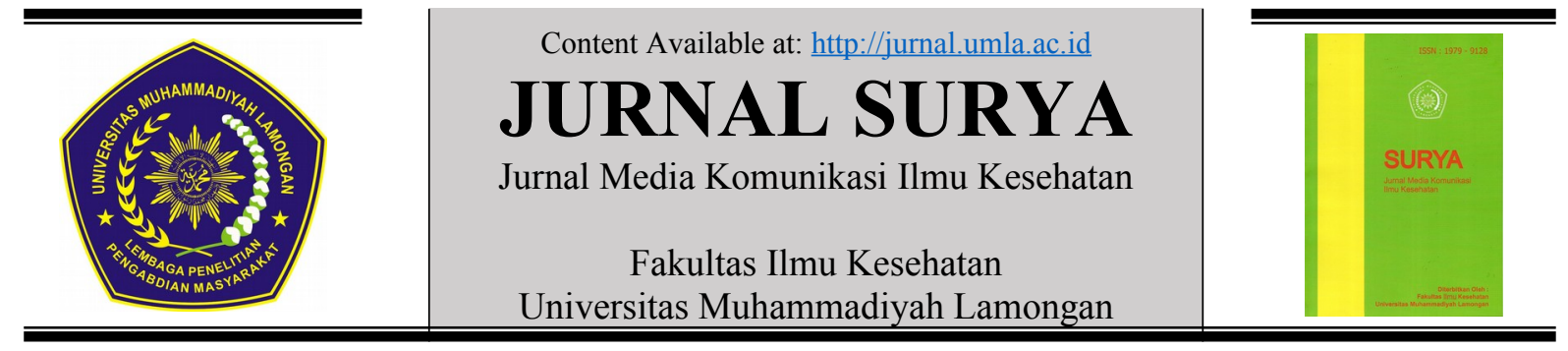

\title{
Hubungan Perilaku Pemberian MP-ASI dengan Status Gizi Bayi 6-24 Bulan di Posyandu Desa Bandung Mojokerto \\ Nanda Devi Kusumaningrum ${ }^{1}$, Puji Hastuti ${ }^{2}$, Ayu Citra Mayasari ${ }^{3}$ \\ ${ }^{1,2,3}$ Sekolah Tinggi Ilmu Kesehatan Hang Tuah Surabaya
}

\section{ARTIKEL INFO}

\section{Article History:}

SM at 09-12-2019

$R V$ at $10-12-2019$

$P B$ at 24-12-2019

\section{Kata Kunci:}

Perilaku Pemberian MP-ASI

Status gizi

Bayi 6-24 bulan

Korespondensi Penulis:

pujihastuti@stikeshangtuahsby.ac.id

\section{ABSTRAK}

Background: Keadaan yang mempengaruhi awal tumbuh kembang adalah nutrisi. Kecukupan gizi dalam makanan menentukan status gizi anak. Perilaku pemberian MP-ASI yang tidak sesuai akan menimbulkan masalah status gizi anak.

Objectives: Penelitian ini bertujuan untuk mengetahui hubungan antara perilaku pemberian MP-ASI dengan status gizi pada bayi yang berusia 6-24 bulan di Posyandu Desa Bandung Mojokerto.

Design: Desain penelitian analitik korelasi menggunakan pendekatan Cross Sectional. Sampel penelitian diambil menggunakan teknik Simple Random Sampling didapatkan sebanyak 67 bayi di Posyandu Desa Bandung Mojokerto. Perilaku pemberian MP-ASI diukur menggunakan Kuesioner dan status gizi bayi menggunakan lembar observasi berat badan bayi, dan tabel antropometri $z$-score. Data dianalisis dengan menggunakan Uji Spearman Rho dengan kemaknaan $(\mathrm{p} \leq 0,05)$.

Results: Hasil penelitian menunjukan hasil perilaku kurang tepat $(53,7 \%)$ pemberian MP-ASI di Posyandu Desa Bandung dan status gizi bayi 6-24 bulan berstatus gizi baik (86,6\%). Uji Spearman Rho menunjukkan hasil ada hubungan antara perilaku pemberian MP-ASI dengan status gizi dengan nilai $p$ value $=0,015(\mathrm{p} \leq 0,005)$ dengan koefisien $\mathrm{r}=0,295$

Conclusions: Ketepatan pemberian MP-ASI menjadi faktor penting. Dari penelitian pengaruh lingkungan dan budaya menjadi salah satu sebab terjadinya pemberian MP-ASI yang tidak tepat. Diperlukan peran aktif orang-orang yang berpengaruh dalam lingkungan tersebut untuk mengajak dan memberikan motivasi serta bantuan dari tenaga kesehatan setempat dalam memberikan health education untuk menambah pengetahuan ibu terlebih dalam pemberian MP-ASI yang tepat dan benar sehingga ibu dapat berperilaku lebih tepat. 
PENDAHULUAN

Keadaan yang mempengaruhi awal tumbuh kembang adalah nutrisi. Kebutuhan bayi akan nutirisi semakin meningkat seiring bertambahnya usia bayi. Oleh karena itu, pada usia 6 bulan bayi mulai diperkenalkan dan diberikan gizi tambahan yang berupa makanan pendamping air susu ibu (MP-ASI) atau makanan tambahan yang bertujuan agar gizi bayi bisa terpenuhi. Makanan Pendamping Air Susu Ibu (MP-ASI) adalah makanan atau minuman yang mengandung zat yang diberikan pada bayi atau anak usia 6-24 bulan guna memenuhi kebutuhan gizi selain ASI. Pemberian MP-ASI merupakan proses transisi asupan dari susu (ASI) menuju makanan keluarga semi padat secara bertahap, seperti jenis, jumlah, frekuensi, maupun tekstur dan konsistensinya sampai kebutuhan bayi terpenuhi (Rotua, Novayelinda, \& Utomo, 2018).

Pemberian MP-ASI yang tidak sesuai akan menimbulkan masalah dalam status gizi anak salah satunya masalah gizi kurang dan gizi buruk (Mufida, Widyaningsih, \& Maligan, 2015). Satu tahun terakhir di Desa Bandung terdapat kasus kematian bayi dengan gejala awal BAB dengan bercampur darah. Pada tahun 2018 akhir, terulang kembali kejadian terdapat bayi dengan $\mathrm{BAB}$ darah encer. Setelah dikaji ibu dari bayi tersebut memberikan MP-ASI sebelum usia 6 bulan dan status gizi satu dari bayi tersebut mengalami gizi lebih. Perilaku juga dipengaruhi oleh pengetahuan, kebudayaan, tingkat pendidikan, dan lain-lain, dalam hal ini pengetahuan ibu sangat berpengaruh dalam hal pemberian MP-ASI .

World Health Organization (WHO) dan UNICEF menyatakan bahwa lebih dari $50 \%$ kematian balita disebabkan oleh keadaan kurang gizi dan dua pertiganya terkait dengan perilaku pemberian makan yang kurang tepat pada bayi dan anak (Gulo \& Nurmiyati, 2015). Indonesia menempati peringkat kelima dunia dalam masalah gizi buruk atau sekitar $3,8 \%$ dari total 87 jumlah anak nasional. Kementerian Kesehatan RI (2018). Provinsi Jawa Timur sendiri pada tahun 2018, angka prosentase balita dengan gizi buruk dan gizi kurang di Jawa Timur sebesar 15\% dan gizi buruk sebanyak 2,5\% jika dijumlahkan maka hasilnya 17,5\% (Dinas Kesehatan Provinsi
Jawa Timur, 2017). Salah satu daerah di provinsi Jawa Timur yang menjadi perhatian lebih dalam masalah gizi buruk ialah Kabupaten Mojokerto. Hasil laporan yang diltulis oleh Chariris (2018), dalam Radar mojokerto, data dari dinas kesehatan Kabupaten Mojokerto sepanjang tahun 2017 terdapat 87 kasus balita yang mengalami gizi buruk dan jumlah ini tersebar dalam 11 kecamatan. Salah satunya di Kecamatan Gedeg yakni dengan 8 kasus balita yang mengalami gizi buruk dari jumlah 994 balita yang tersebar di 14 desa di Kecamatan Gedeg. Dari 8 kasus tersebut diantaranya berasal dari Desa Bandung.

Pemberian MP-ASI yang tidak tepat dan tidak sesuai dengan usia akan menyebabkan gangguan dalam pemenuhan kebutuhan nutrisi bayi dan juga gangguan pencernaan bayi. Sistem pencernaan bayi yang berusia kurang dari 6 bulan belum siap untuk menerima makanan semi padat dan beresiko terkena masalah ganngguan pencernaanya seperti diare dan berak darah. Pemberian MP-ASI yang tidak sesuai akan berakibat pada status gizi anak yang tidak terpenuhi, dan pemberian MP- ASI yang melebihi pemberian akan mengakibatkan gizi anak lebih (overweight) dan obesitas.

Pemerintah berkomitmen untuk menurunkan angka permasalahan gizi di Indonesia. Salah satu program pemerintah tersebut ialah pemenuhan gizi 1000 HPK (Hari Pertama Kelahiran) yaitu dimulai sejak fase kehamilan (270 hari) hingga anak berusia 2 tahun. Orang tua perlu mengetahui dengan benar dalam pemenuhan gizi selama hamil dan 1000 hari selanjutnya sehingga status gizi akan terpenuhi. Orang tua sebaiknya memperhatikan kebutuhan nutrisi dini anaknya dan melakukan pemeriksaan kesehatan rutin bayinya di posyandu atau layanan kesehatan setempat. Berdasar fenomena tersebut peneliti ingin melakukan penelitian untuk mengetahui hubungan salah satu faktor penyebab perubahan status gizi diantaranya perilaku dalam pemberian MPASI dengan keadaan status gizi bayi 6-24 bulan di Posyandu Desa Bandung Kecamatan Gedeg Kabupaten Mojokerto. 


\section{METODE}

Penelitian ini menggunakan desain penelitian dengan metode analitik korelasi degan pendekatan Cross Sectional bertujuan untuk mencari hubungan . Instrument yang digunakan dalam penelitian ini menggunakan 3 instrumen yaitu untuk mengukur perilaku pemberian MP-ASI berupa lembar kuesioner dan wawancara terstruktur, lembar observasi pengukuran berat badan (BB) dan tabel antropometri dengan menilai $z$-score kemudian membandingkan dengan nilai standar deviasi pada kategori gizi menurut Depkes RI. Teknik sampling pada penelitian ini meggunakan Probability Sampling dengan pendekatan Simple Random Sampling dan didapatkan sampel sebanyak 67 responden ibu bayi dan bayi 6-24 bulan. Penelitian ini dilakukan di Posyandu Desa Bandung, Kecamatan Gedeg, Kabupaten Mojokerto.

\section{HASIL dan PEMBAHASAN}

1. Perilaku Ibu dalam Pemberian MP-ASI Di Posyandu Desa Bandung Mojokerto

Tabel 1 Perilaku Pemberian Mp- Asi Bayi 624 Bulan Di Posyandu Desa Bandung Mojokerto

\begin{tabular}{lcc}
\hline $\begin{array}{c}\text { Perilaku Pemberian } \\
\text { MP- ASI }\end{array}$ & F & \% \\
\hline Tidak Tepat & 11 & 16,4 \\
Kurang Tepat & 36 & 53,7 \\
Tepat & 20 & 29,9 \\
\hline Total & $\mathbf{6 7}$ & $\mathbf{1 0 0}$ \\
\hline
\end{tabular}

Tabel 1 menunjukkan bahwa dari 67 Ibu responden di Posyandu Desa Bandung sebagian besar masih memiliki perilaku kurang tepat dalam pemberian MP-ASI kepada anaknya yakni sebanyak 36 orang $(53,7 \%)$.

Hasil crosstabulation perilaku kurang tepat tertinggi domisan pada kategori pekerjaan orang tua didapatkan hasil hasil perilaku kurang tepat terbanyak dengan ibu yang bekerja sebanyak 34 orang (94\%). Peneliti berasumsi bahwa ibu bekerja akan memiliki sedikit waktu untuk anaknya tertama dalam pengasuhan anak sehingga pekerjaan rumah termasuk mengurus anak perlu bantuan dari orang lain seperti pembantu rumah tangga, ibu asuh atau penagasuh dari keluarga terdekat sehingga perilaku ibu dalam memberikan MP-ASI kurang tepat. Hal ini sesuai dengan penelitian dari Sari (2018), dalam penelitiannya mengatakan ibu yang tidak bekerja lebih memiliki pola asuh yang baik kepada anaknya, ibu bisa lebih memperhatikan tumbuh kembang anaknya dan pola asuh dalam memenuhi gizi anaknya. Sejalan dengan penelitian dari Grzywacs, G, Tucker, Clinch, \& Arcury, (2010) menurut hasil penelitiannya mengatakan bahwa ibu yang bekerja memberikan makan secara komersial artinya ibu memberikan apa saja untuk anaknya tanpa mengetahui takaran, porsi, dan kandungan gizi yang tepat untuk anaknya, sehingga perilaku yang kurang tepat ini bisa menimbulkan risiko kesehatan dan perkembangan untuk anaknya. Hal ini juga dibuktikan dengan nilai terendah pengisian kuesioner berada pada no 6 tentang porsi pemberian MP-ASI dengan pernyataan "Saya memberikan makanan tambahan anak saya 1 mangkok kecil penuh setiap kali makan", berdasarkan hasil tersebut bisa dikatakan bahwa dari $36 \mathrm{ibu}$ yang menjawab tidak tepat sebanyak 23 orang dengan usia bayi kurang dari 12 bulan yakni ibu bayi dengan usia bayi 9 bulan sebanyak 9 orang, berusia 10 bulan sebanyak 8 orang dan berusia 11 bulan sebanyak 6 orang.

Kategori perilaku pemberian MP-ASI terbesar kedua ialah perilaku tepat yakni sebanyak 20 responden $(29,9 \%)$ yang dilihat dari usia ibu. Hasil crosstabulation antara usia bayai dengan perilaku menyatakan ibu dengan usia bayi 12-24 bulan sebanyak 11 ibu bayi dengan perilaku pemberian MP-ASI yang tepat. Menurut peneliti perilaku tersebut bisa memungkinkan karena pengalaman ibu dengan usia ibu diatas 30 tahun. Hasil mean kategori usia ibu ialah usia 32 tahun, usia tersebut merupakan usia yang siap atau matang dalam hal pengasuhan anak. Menurut peneliti ibu dengan usia lebih dari 30 tahun akan lebih siap untuk menjadi ibu dalam pengasuhan anaknya dan telah memiliki pengalaman yang cukup. Hal ini sesuai dengan penelitian dari Dewi (2013), dalam penelitiannya menyebutkan bahwa semakin dewasa usia akan semakin matang dalam bersikap dan bertindak. Hal ini juga sejalan dengan hasil. Hal ini sesuai juga dengan penelitian dari Aziza dan Mugiati dalam Aji, 
Wati, \& Rahardjo (2016), hasil menunjukkan bahwa ibu dengan usia dibawah 30 tahun akan mempengaruhi perilaku pola pengasuhan pemberian makanan. Berdasar hasil kuesioner perilaku pemberiam MP-ASI dengan nilai tertinggi pada no 9 tentang frekuensi pemberian MP-ASI dengan pernyataan "Saya memberikan anak saya makanan tambahan sebanyak 3 kali sehari", berdasarkan hasil tersebut bisa dikatakan bahwa ibu memberikan MP-ASI ke anaknya sebanyak 3 kali sehari. Anjuran menurut Depkes RI yang benar memang memberikan MP-ASI 3x sehari yakni dengan 2 kali makanan utama dan 1 selingan seperti snack atau makanan selingan. Dari 67 total ibu bayi, yakni sebanyak $42 \mathrm{ibu}$ (63\%) menjawab benar tentang frekuensi pemberian MP-ASI yang sudah sesuai dengan usia bayinya.

Prosentase terendah pada kategori perilaku pemberian MP-ASI perilaku adalah tidak tepat yakni sebesar 11 orang $(16,4 \%)$ dari total 67 responden. Perilaku sangat berhubungan dengan pendidikan dan pengetahuan. Hasil kuesioner terendah kedua berada di nomor 3 yakni tentang tekstur MPASI dengan pernyataan "Saya memberikan makanan tambahan anak saya berupa bubur tim saat anak saya berusia 6-8 bulan". Hampir semua responden dalam memberikan MP-ASI salah, dimana anak sudah diberikan MP- ASI saat usia kurang dari 6 bulan. Hasil crosstabulation data umum dan data khusus didapatkan bahwa dari yang memiliki hasil dominan dalam kategori perilaku tidak tepat tertinggi berada di kategori pendidikan terakhir ibu yaitu pendidikan terakhir SD sebanyak 2 responden $(100 \%)$ dari jumlah total 2 responden yang berpendidikan terakhir SD.

Hal ini dapat dijelaskan bahwa semakin tinggi ilmu seseorang maka akan semakin tinggi tingkat pengetahuannya. Peneliti berpendapat pendidikan ibu merupakan salah satu faktor yang mempengaruhi tingkat pengertian dan pemahaman perawatan kesehatan, terutama kesehatan keluarga karena ibu merupakan pengasuh utama didalam keluarga. Tingkat pendidikan ibu menentukan sikap dan intervensi pelaksanaan dalam menghadapi berbagai macam msalah kesehatan.

Hasil tersebut sejalan dengan penelitian dari Aridiyah, Rohmawati, \&
Ririanty (2015) mengatakan tingkat pendidikan ibu akan mempengaruhi kemampuan dan pengetahuan ibu mengenai perawatan kesehatan terutama dalam memahami pengetahuan mengenai gizi.

2. Status Gizi Bayi 6-24 Bulan Di Posyandu Desa Bandung Mojokerto

Tabel 2 Distribusi Status Gizi Bayi 6- 24 Bulan Di Posyandu Desa Bandung

\begin{tabular}{lcc}
\hline \multicolumn{1}{c}{ Status Gizi } & F & \% \\
\hline Gizi Buruk Gizi & 2 & 3,0 \\
Kurang Gizi & 5 & 7,5 \\
Baik & 58 & 86,6 \\
Gizi Lebih & 2 & 3,0 \\
\hline Total & $\mathbf{6 7}$ & $\mathbf{1 0 0}$ \\
\hline
\end{tabular}

Status gizi pada kategori baik dan lebih menempati prosentase terbesar dalam penelitian ini. Kategori gizi baik yakni 58 bayi dan gizi lebih sebanyak 2 bayi. Untuk bayi dengan gizi baik, 39 (68\%) bayi berasal dari keluarga dengan pendapatan lebih dari 3 juta dan 16 bayi (32\%) berasal dari keluarga dengan penghasilan 3 juta. Sementara untuk bayi dengan gizi lebih terdapat 2 bayi (100\%) bersal dari keluarga dengan penghasilan 3 juta. Hal ini membuktikan bahwa status gizi bayi dipengaruhi oleh pendapatan keluarga. Pendapatan ialah bentuk pengahsilan atau penerimaan nyata dari seluruh anggota keluarga untuk memenuhi kebutuuhan rumah tangga. Ibu berpendapat bahwaanaknya suka makan dan memakan camilan, ibu suka anaknya berbadan besar. Gizi lebih sangat beresiko pada tumbuh kembang anak dan gerak motorik anak yang berakibat gerak anak menjadi tidak leluasa. Hal ini sesuai dengan penelitian yang dilakukan oleh Mulazimah (2017), dalam penelitiannya ia menjelaskan bahwa penghasilan yang berlebihan, jika tidak diperhatikan dalam pemberiannya kepada bayi, maka pertumbuhan dan perkembangan anak mereka akan terganggu karena ketidakseimbangan zat gizi yang diperlukan dengan zat gizi yang diterima.

Selain gizi baik dan lebih, di Posyandu Desa Bandung juga terdapat bayi dengan gizi buruk dan kurang. Bayi dengan gizi buruk berjumlah 2 bayi $(3,0 \%)$, dan gizi kurang sebanyak 5 bayi (7,5\%). Bayi yang menderita gizi buruk tersebut berasal dari keluarga dengan ekonomi menengah 
kebawah yakni keluarga dengan penghasilan kurang dari 3 juta. Dan untuk gizi kurang 1 bayi $(20 \%)$ berasal dari keluarga dengan penghasilan kurang dari 3 juta dan 4 bayi $(80 \%)$ berasal dari keluarga dengan penghasilan 3 juta. Hal ini bisa dikatakan bahwa keluarga dengan penghasilan 3 juta dan diatas 3 juta bisa memenuhi gizi bayinya sehingga gizi bayinya tercukupi.

Peneliti berpendapat semakin tinggi pendapatan maka kualitas dan kuantitas makanan akan membaik jugaa. Hal ini sejalan dengan penelitian dari Ukuwani, Fetus, Suchindra, \& Chirayath (2003) dalam penelitiannya ia menyebutkan pada daerah urban di Guatemala menemukan bahwa penghasilan ibu mempunyai efek yang positif pada status gizi anak. Pendapatan keluarga memadai akan menunjang tumbuh kembang anak, karena orang tua dapat menyediakan semua kebutuhan anak baik primer maupun sekunder (Indarti, 2016). Sejalan dengan penelitian dari Hadju, Yunus, Arundhana, Salmah, \& Wahyu (2017) dalam Asian Journal of Clinical Nutrition mengatakan bahwa sosiak ekonomi keluarga berpengarruh pada stastus nutrisi bayi, penelitiannya menunjukkan prevalennsi bayi di bawah 2 tahun memiliki berat badan kurang, kurang tinggi dan kurus dengan sosial ekonomi yang rendah. Namun, hal ini tidak sejalan dengan penelitian yang dilakukan oleh Rias (2016), hasil penelitiannya mengatakan tidak terdapat hubungan antara pendapatan dengan status gizi. Ia berpendapat masalah gizi bersifat multikompleks yang artinya banyak faktor yang mempengaruhi karena tidak hanya faktor ekonomi yang berperan tetapi faktorfaktor lain juga ikut menentukan.

3. Hubungan Perilaku Pemberian MPASI dengan Status Gizi Bayi 6-24 Bulan Di Posyandu Desa Bandung Mojokerto

Tabel 3 Hubungan Perilaku Pemberian MPASI Dengan Status Gizi Bayi 6- 24 Bulan Di Posyandu Desa Bandung

\begin{tabular}{|c|c|c|c|c|c|c|c|c|c|}
\hline \multirow{3}{*}{$\begin{array}{l}\text { Perilaku } \\
\text { pemberian } \\
\text { MP.ASI }\end{array}$} & \multicolumn{9}{|c|}{ Status Gizi } \\
\hline & \multicolumn{2}{|c|}{ Gizi Bunk } & \multicolumn{2}{|c|}{ Gizi Kurang } & Gizi Baik & \multicolumn{2}{|c|}{ Gizi Lebih } & \multicolumn{2}{|c|}{ Total } \\
\hline & $\mathrm{F}$ & $\%$ & F & $\%$ & $\%$ & $\mathrm{~F}$ & $\%$ & $F$ & $\%$ \\
\hline Tidak Tepat: & 2 & 18,2 & 4 & 36,4 & \begin{tabular}{|ll}
3 & 27,3
\end{tabular} & 2 & 18,2 & 11 & 100 \\
\hline Kurang Tepat & 0 & 0,0 & 1 & 2,8 & $35 \quad 97,2$ & 0 & 0,0 & 36 & 100 \\
\hline Tepat & 0 & 0,0 & 0 & 0,0 & $20 \quad 100$ & 0 & 0,0 & 20 & 100 \\
\hline Total & 2 & 3,0 & 5 & 7,5 & $\begin{array}{ll}58 & 86,6 \\
\end{array}$ & 2 & 3,0 & 67 & 100 \\
\hline
\end{tabular}

Tabel 3 menunjukkan bahwa dari 67 responden dengan perilaku pemberian MPASI tidak tepat sebanyak 11 responden memiliki status gizi buruk sebanyak 2 bayi $(18,2 \%)$, gizi kurang sebanyak 4 bayi $(36,4 \%)$, gizi baik sebanyak 3 bayi $(27,3 \%)$, dan gizi lebih sebanyak 2 bayi $(18,2 \%)$. Kemudian responden dengan perilaku pemberian MP-ASI yang kurang tepat berjumlah 36 bayi dengan status gizi kurang sebanyak 1 anak (2,8\%), gizi baik sebanyak 35 anak $(97,2 \%)$, dan tidak ada yang memiliki stastus gizi lebih (0\%). Sedangkan responden dengan perilaku pemberian MP-ASI yang tepat memiliki status gizi gizi baik sebanyak 20 bayi (100\%) dan tidak memiliki status gizi buruk, status gizi kurang dan status gizi lebih (0\%).

Hasil pengolahan dan analisis data didapatkan dari penelitian hubungan perilaku pemberian MP- ASI dengan status gizi bayi 624 bulan di Posyandu Desa Bandung Mojokerto pada tanggal 4-11 Mei 2019 adalah terdapat hubungan perilaku pemberian MP-ASI dengan status gizi bayi 6-24 bulan di Posyandu Desa Bandung. Hal ini sesuai dengan hasil uji korelasi antar variabel Spearman Rho dengan hasil kemaknaan $\mathrm{p}=0,015 \quad(\mathrm{p}=<0,05)$. Hasil yang menonjol ialah perilaku tidak tepat dengan gizi baik. Manurut peneliti jika pemberian MP-ASI yang benar akan sangat berpengaruh pada proses tumbuh kembang anak dan kecerdasannya. Sejalan dengan penelitian dari Mufida et al. (2015) Pemberian MP-ASI yang tidak sesuai akan menimbulkan masalah dalam status gizi anak salah satunya masalah gizi kurang dan gizi buruk.

Penyebab utama terjadinya gizi kurang dan hambatan pertumbuhan pada anak-anak usia 3- 15 bulan berkaitan dengan rendahnya pemberian ASI dan buruknya praktek pemberian makanan pendamping ASI. Perilaku pemberian MP-ASI sendiri bisa dipengaruhi oleh budaya masyarakat maupun lingkungan sekitar. Hal ini dikarenakan masih banyak keluarga yang tinggal dengan keluarga yang lain atau dengan kata lain satu rumah terdapat beberapa kepala keluarga, sehingga budaya dan lingkungan sangat berperan dalam perilaku pengasuhan anak termasuk pemberian MP-ASI. Hal ini sesuai dengan penelitian dari Utami (2010), hasil penelitiannya mengatakan bahwa salah satu 
faktor yang mempengaruhi pemberian MPASI sebelum usia 6 bulan ialah kultur atau budaya turun-temurun dari keluarga maupun tetangga sekitar rumah.

Lingkungan tetangga yang memiliki pengalaman tidak benar sebelumnya yang mengakibatkan pemberian MP- ASI kurang dari 6 bulan. Hal ini sesuai penelitian dari Manikam et al. (2018) ia mengatakan bahwa yang mempengaruhi perubahan gizi di India ialah termasuk faktor pengaruh budaya, pengetahuan yang rendah tentang pemberian MP-ASI dan stastus pendidikan orang tua.

Beberapa penelitian lain juga menyatakan bahwa keadaan perubahan status gizi pada bayi dan anak disebabkan karena pemberian MP-ASI yang tidak tepat. Keadaan ini memerlukan penanganan tidak hanya penyediaan pangan, tetapi juga pendekatan yang komunikatif sesuai dengan tingkat pendidikan dan kemampuan masyarakat. Selain itu, umur pertama kali pemberian MPASI sangat penting dalam menentukan status gizi bayi. Makanan prelaktal maupun MP-ASI dini mengakibatkan kesehatan bayi menjadi rapuh dikarenakan sistem pencernaan bayi yang belum siap untuk menerima makanan.

\section{KESIMPULAN}

\section{Kesimpulan}

1) Perilaku pemberian MP-ASI di Posyandu Desa Bandung Mojokerto sebagian besar ibu bayi yang memberikan makanan pendamping ASI dengan perilaku kurang tepat.

2) Status gizi bayi di Posyandu Desa Bandung Mojokerto hampir seluruhnya dengan status gizi baik.

3) Perilaku pemberian MP-ASI ada hubungan dengan status gizi bayi 6-24 bulan di Posyandu Desa Bandung Mojokerto.

\section{Saran}

1) Bagi Keluarga

Hendaknya memberikan MP- ASI yang tepat dan benar pada sesuai dengan usianya serta terpenuhinya asupan nutrisi yang seimbang.

2) Bagi Tempat Penelitian

Memberikan health education mengenai pentingnya memberikan MP-ASI yang benar dan tepat usia serta cara memenuhi kebutuhan asupan gizi yang cukup dan seimbang untuk balita.

3) Bagi Peneliti Selanjutnya

Referensi untuk penelitian lebih lanjut tentang perilaku pemberian MP-ASI dengan status gizi bayi 6-24 bulan.

\section{DAFTAR PUSTAKA}

Aji, D. S. K., Wati, E. K., \& Rahardjo, S. (2016). Analisis Faktor- Faktor Yang Berpengaruh Terhadap Pola Asuh Balita Di Kabupaten Banyumas. Jurnal Kesmas Indonesia, 8, 1-15.

Aridiyah, F. O., Rohmawati, N., \& Ririanty, M. (2015). Faktor- Faktor Yang Mempengaruhi Kejadian Stunting Pada Anak Balita Di Wilayah Pedesaan Dan Perkotaan (The Factors Affecting Stunting On Toddlers In Rural And Urban Areas), $3(1)$.

Chariris, M. (2018, January). Miris, 87 Balita Di Kabupaten Mojokerto Alami Gizi Buruk. Radarmojokerto.Id. Retrieved From Https://Radarmojokerto.Jawapo s.Com/Read/2018/01/27/4417/ Miris87-Balita-Di-Kabupaten- MojokertoAlami-Gizi-Buruk

Depkes RI (2007). Buku Pedoman Pemberian Makanan Pendamping Asi. Jakarta: Ditjen Bina Kesehatan Masyarakat Dan Direktorat Bina Gizi Masyarakat.

Dewi, U. M. (2013). Pengaruh Karakteristik Ibu Terhadap Pemberian Asi Eksklusif Pada Bayi Usia 0-6 Bulan Di Bpm Nurul Trianawati, Sst Surabaya, 146-150.

Dinas Kesehatan Provinsi Jawa Timur. (2017). Profil Kesehatan Jawa Timur. Education On Child's Nutritional Status In The Slums Of Nairobi. Bmc Pediatrics, $\quad 12 \quad$ (1998). Https://Doi.Org/10.1186/1471- 2431$\underline{12-80}$

Grzywacs, G, J., Tucker, J., Clinch, C., \& Arcury, T. A. (2010). Individual 
And Job-Related Variation In Infant Feeding Practices Among Working Mothers. American Journal Of Health Behavior, 34(2), 186196(11).

Https://Doi.Org/Https://Doi.Org/10.5 993/Ajhb.34.2.6

Gulo, M. J., \& Nurmiyati, T. (2015). Hubungan Pemberian Mp Asi Dengan Status Gizi Bayi Usia 6- 24 Bulan Di Puskesmas Curug Kabupaten Tangerang. Jurnal Bina Cendekia Kebidanan, 1.

Hadju, V., Yunus, R., Arundhana, A. I., Salmah, A. U., \& Wahyu, A. (2017). Nutritional Status Of Infants 0-23 Months Of Age And Its Relationship With Socioeconomic Factors In Pangkep. Asian Journal Of Clinical Nutrition, 9(2), 71-76. Https://Doi.Org/10.3923/Ajen.2 $\underline{017.71 .76}$

Indarti, Y. (2016). Hubungan Status Ekonomi Keluarga Dengan Status Gizi Balita Di Kecamatan Ajung Kabupaten Jember Tahun 2016, 15(1), 149-162

Kementerian Kesehatan RI. (2018). Hasil Utama Riset Kesehatan Dasar.

Manikam, L., Prasad, A., Dharmaratnam, A., Moen, C., Robinson, A., Light, A., ... Lakhanpaul, M. (2018). Systematic Review Of Infant And Young Child Complementary Feeding Practices In South Asian Families: The India Perspective. Public Health Nutrition, 21(4),637-654.

Https://Doi.Org/10.1017/S1368 98001700297x

Mufida, L., Widyaningsih, T. D., \& Maligan, J. M. (2015). Prinsip Dasar Makanan Pendamping Air Susu Ibu ( Mp-Asi ) Untuk Bayi 6 - 24 Bulan: Kajian Pustaka, 3(4), 1646-1651.

Mulazimah. (2017). Hubungan Pendapatan Keluarga Dengan Status Gizi Balita Desa Ngadiluwih Kecamatan
Ngadiluwih Kabupaten Kediri, (2013), 18-21.

Rias, Y. A. (2016). Nutrisi Sang Buah Hati: Bukti Cinta Ibu Cerdas. Yogyakarta: Gosyen Publishing.

Rotua, D. F., Novayelinda, R., \& Utomo, W. (2018). Identifikasi Perilaku Ibu Dalam Pemberian Mp-Asi Dini Di Puskesmas Tambang Kabupaten Kampar. Journal Of Maternity, 5, 110.

Sari, M. R. (2018). Hubungan Perilaku Pemberian Makanan Pendamping Asi (Mp-Asi) Dengan Status Gizi Bayi 612 Bulan Di Wilayah Kerja Puskesmas Poasia Kota Kendari Tahun 2018.

Ukuwani, Fetus, A., Suchindra, \& Chirayath, M. (2003). Implication Of Woman's Work For Child Nutritional Status In Sub Saharan Africa: A Case Study Of Nigeria. Social Science And Medicine, 56.

Utami, L. H. (2010). Budaya Pemberian Makanan Pendamping Asi Dini Pada Ibu Yang Mempunyai Anak 724 Bulan Di Desa Argodadi Sedayu Bantul Yogyakarta. Skolastik Keperawatan. 